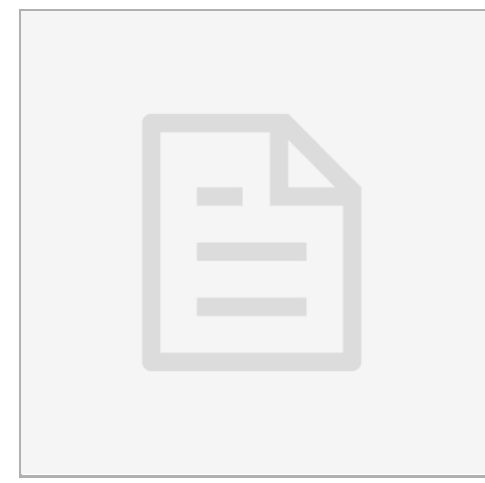

VERSION 1

AUG 17, 2020

open ○access

DOI:

dx.doi.org/10.17504/protocol s.io. bjtkknkw

Protocol Citation: Norma McFarlane-Anderson 2020. Indirect Enzyme Linked Immunosorbent Assay (ELISA) for Detection of Anti-HIV Antibodies in Human Serum. protocols.io

https://dx.doi.org/10.17504/p rotocols.io.bjtkknkw

License: This is an open access protocol distributed under the terms of the Creative Commons Attribution License, which permits unrestricted use, distribution, and reproduction in any medium, provided the original author and source are credited

Protocol status: Working We use this protocol and it's working

Created: Aug 16, 2020

Last Modified: Aug 17, 2020

PROTOCOL integer ID:

40524

\section{(3) Indirect Enzyme Linked Immunosorbent Assay (ELISA) for Detection of Anti-HIV Antibodies in Human Serum V.1}

\author{
Norma McFarlane-Anderson ${ }^{1}$ \\ ${ }^{1}$ University of the West Indies, Mona \\ University of the West Indies angel.vaillant@sta.uwi.edu
}

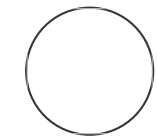

Angel A Justiz-Vaillant

University of the West Indies St. Augustine

\section{DISCLAIMER}

\section{DISCLAIMER - FOR INFORMATIONAL PURPOSES ONLY; USE AT YOUR OWN RISK}

The protocol content here is for informational purposes only and does not constitute legal, medical, clinical, or safety advice, or otherwise; content added to protocols.io is not peer reviewed and may not have undergone a formal approval of any kind. Information presented in this protocol should not substitute for independent professional judgment, advice, diagnosis, or treatment. Any action you take or refrain from taking using or relying upon the information presented here is strictly at your own risk. You agree that neither the Company nor any of the authors, contributors, administrators, or anyone else associated with protocols.io, can be held responsible for your use of the information contained in or linked to this protocol or any of our Sites/Apps and Services.

\section{ABSTRACT}

This protocol was already used successfully to detect anti-HIV antibody in the serum of women with cervical dysplasia or cervical cancer in Jamaica, West Indies [1].

\section{Reference}

1. Justiz Vaillant A, Bazuaye PE, McFarlane-Anderson N, Smikle MF et al. Seroprevalence of Anti-HIV Antibodies in Women with Abnormal Pap Smears in Jamaica. British Journal of Medicine \& Medical Research 2013, 3(4): 2197-2202. 
1 The 96 well polystyrene microplate (U-shaped bottom; Sigma-Aldrich) is coated with $50 \mathrm{ng}$ of a mixture of synthetic peptides (including the fragment 579-601 of the HIV gp41 and fragments 254-274, 308-331 and $421-438$ of the HIV gp120) for $4 \mathrm{~h}$ at $37^{\circ} \mathrm{C}$.

2 The microplate is blocked with $3 \%$ non-fat milk in PBS, $25 \mu \mathrm{l} /$ well, $1 \mathrm{~h}$ at room temperature (RT).

3 The microplate is washed $4 \mathrm{X}$ with PBS-Tween-20.

4 Duplicates of $25 \mu \mathrm{l}$ of 1:16 diluted human sera are added.

5 After incubation for 90 min at RT the microplate is washed 4X with PBS-Tween 20.

6 Then, $25 \mu$ l of a chimeric commercially-prepared recombinant protein LA-HRP conjugate (SigmaAldrich) diluted 1:5000 is added.

7 After incubation for $90 \mathrm{~min}$ at RT and rewashing steps $25 \mu \mathrm{ITMB}$ is added to each well for $15 \mathrm{~min}$ in the dark.

8 The reaction is stopped with $3 \mathrm{M} \mathrm{H} 2 \mathrm{SO} 4$.

9 The microplate is read in a microplate reader at $450 \mathrm{~nm}$. 
10 In the ELISA is included a pooled human sera with high titre of anti-HIV antibodies as positive control, a pooled sera from healthy individuals as negative control and $0.9 \%$ normal saline solution was used as the blank.

11 The cut-off point is calculated as mean optical density (XOD) of negative control plus two standard deviation (SD). 